Revista de Filología Románica

ISSN: 0212-999X

http://dx.doi.org/10.5209/RFRM.58348

\title{
La poética palimpséstica de Ricardo Gil Soeiro: los espectros lingüísticos y culturales de la tradición clásica
}

\author{
Armando Pego Puigbó ${ }^{1}$
}

Recibido: 7 de junio de 2016 / Aceptado: 10 de diciembre de 2016

Resumen. La publicación de la tetralogía Palimpsesto (2016) del poeta portugués Ricardo Gil Soeiro constituye una sorprendente aportación dentro del ámbito literario peninsular a las relaciones entre filosofía y literatura. Ante las consecuencias nihilistas de la deconstrucción, ensaya las posibilidades impotentes que todavía contiene la creación poética. Este artículo quiere resaltar dos de sus aspectos: la base hermenéutica de la dialéctica de los deícticos personales y las huellas espectrales de la tradición clásica grecorromana.

Palabras clave: Literatura portuguesa siglo XXI; Poesía; Filosofía; Palimpsesto, Ricardo Gil Soeiro.

\section{[en] The poetics of the palimpsest in Ricardo Gil Soeiro: the linguistic and cultural specters of the classical tradition}

\begin{abstract}
The publication of the tetralogy Palimpsesto (2016) by the Portuguese poet Ricardo Gil Soeiro represents an amazing contribution within the literary field of the Iberian studies to the relationship between philosophy and literature. In front of the nihilistic consequences of the deconstruction, it tests the powerless possibilities that the poetic creation could contain yet. This paper tries to highlight two of its aspects: the hermeneutic base for a dialectics of the personal pronouns and the spectral traces of the Greek-Roman classical tradition.

Key words: 21 st Century Portuguese Literature; Poetry; Philosophy, Palimpsest; Ricardo Gil Soeiro.

Sumario. 1. Una poética palimpséstica, bajo la sombra de Walter Benjamin; 2. Da vida das marionetas: Una dramaturgia del nombre inanimado; 3. Bartlebys reunidos: La abstención creadora como una ética de la impotencia; 4. Comércio com Fantasmas y Anjos necessários: los espectros de Ovidio y Sócrates. 5. Conclusiones palimpsésticas.
\end{abstract}

Cómo citar: Pego Puigbó, A. (2017). La poética palimpséstica de Ricardo Gil Soeiro: los espectros lingüísticos y culturales de la tradición clásica, en Revista de Filología Románica 34.2, 229-245.

\footnotetext{
Facultat de Filosofia. Universitat Ramon Llull apego@filosofia.url.edu
} 


\section{Una poética palimpséstica, bajo la sombra de Walter Benjamin.}

Hace un lustro salieron en dos editoriales diferentes, con una diferencia de apenas seis meses, los dos primeros volúmenes poéticos de la Tetralogía palimpséstica de Ricardo Gil Soeiro (Lisboa, 1981) con los títulos de Da vida das Marionetas (Gil Soeiro 2012) y Bartlebys reunidos (Gil Soeiro 2013), los cuales llevaban como subtítulos respectivos "Para uma Dramatúrgia do Corpo Inanimado" y "Para uma Ética da Impotência". En un gesto que se puede entender principalmente por razones comerciales, a los dos libros publicados se le unen los dos que faltaban entonces, Comércio com Fantasmas (2014) y Anjos Necessários (2015), bajo el título general de Palimpsesto (Gil Soeiro, 2016)2. Los inéditos se incorporan al conjunto no simplemente para completar su sentido, sino para profundizar en el proyecto inicial de una poética palimpséstica que busca transcribirse también como glosa, es decir, como hipertexto que tantea lo que queda por venir: su lectura crítica. Los subtítulos de las dos últimas entregas son también significativos a la hora de poder avanzar una interpretación global de la obra: "Para uma Epistolografia Espectral" y "Para uma Escrita do Desejo".

Como la relación que se forja entre el lector y el autor está tejida por un complejo y delicado juego entre los deícticos personales (Luján Atienza 2005: 305-321), una lección de la poesía moderna que puede aplicarse a la obra de Gil Soeiro consiste en que no hay más lector que el que llega demasiado tarde. Es decir, aquel que lee no sólo interpreta, sino que vuelve a escribir sobre el texto su interpretación, como uno de los efectos de sentido que el poema propone ${ }^{3}$.

De la lectura de la tetralogía al completo se obtiene la visión de una obra autoconscientemente posmoderna, pero no por ello menos ambiciosa desde un punto de vista creativo. Gil Soeiro, una de las voces prometedoras de la reciente poesía portuguesa, ante la que se dio a conocer en 2010 con la publicación de $O$ Alfabeto dos Astros (2010), es un ejemplo de la figura de poeta-investigador universitario. Sus estudios en literatura comparada, teoría de la literatura y escritura de la memoria no son sólo un complemento formativo que pesa sobre su escritura poética, sino que constituyen su entramado mismo. No se trata de una poesía que utilice los motivos, los procedimientos o la jerga académica para construir sus artefactos literarios, sino que éstos forman parte de un único proceso investigador que experimenta formal y genéricamente las potencialidades del significado en un paradigma epocal que se ha caracterizado por el eclipse del logos, como ha estudiado el propio Gil Soeiro a propósito de George Steiner desde su primera obra, Iminência do Encontro (2010), Premio a la Primera Obra del PEN Club Portugués.

Su poesía, pues, se encuentra en la intersección entre la errata, entendida en su valor polisémico entre error y errar, y el palimpsesto, como la traza superpuesta que continúa, pero no funda, el movimiento significante. Bien podría aplicarse a su tetralogía su comprensión de la autobiografía intelectual del mismo Steiner:

Esta obra ha sido candidata al Premio al Mejor Libro de Poesía de la Sociedade Portuguesa de Autores 2017.

« C'est l'Ennui ! -L'œil chargé d'un pleur involontaire, / Il rêve d'échafauds en fumant son houka. / Tu le connais, lecteur, ce monstre délicat, / - Hypocrite lecteur, - mon semblable, - mon frère ! » (Baudelaire 3). Esta relectura del tedio en la obra de Gil Soeiro supone la conciencia de una posposición, es decir, de que la palabra poética llega siempre después, de que la inscripción, lingüística o cultural, que instaura el poema se ejerce como un momento de desposesión que hace infundado todo sentido posible, aunque no por ello sea menos efectivo o real. 
"Extemporânea e intempestiva, estigmatizando après coup o livro, a errata, sendo uma excrecência do livro, é afinal um corpo suplementar ao qual subjaz a declaraçâo formal e a lúcida percepçâo de que o livro ja lido ou por ler se tornou provisório no próprio momento da sua elaboraçâo ainda antes de chegar às mâos do leitor" (Gil Soeiro 2009: 55).

Al utilizar el término "palimpsesto" se puede uno imaginar retornando a un concepto que hizo furor en el postestructuralismo, a partir del concepto de "intertextualidad" que introdujo Julia Kristeva en su artículo "Bajtín, la palabra, el diálogo y la novela". ¿Cómo es posible no recordar también el clásico libro de Gérard Genette Palimpsestos (Genette 1989)? Para Gil Soeiro el palimpsesto no puede ser reducido a un procedimiento compositivo, por más que sirva para horizontalizar el flujo de las relaciones textuales. Mucho menos puede hablarse en rigor de una dependencia jerárquica en cuanto transformación textual de un precedente que pueda considerarse "origen". En su ensayo decía Kristeva que M. Bajtin había introducido en la teoría literaria el descubrimiento de que "todo texto se construye como un mosaico de citas, todo texto es absorción y transformación de otro texto" (Kristeva 3). Gil Soeiro parece querer dar un paso más allá y entender el palimpsesto como una categoría arquitectónica, es decir, como una de las formas de "entender el objeto estético en su especificidad puramente artística, asi como también su estructura" (Bajtin 23), en tanto que "las principales formas arquitectónicas son comunes a todas las artes y al entero dominio de lo estético, constituyendo la unidad de ese dominio" (Bajtin 27).

Los poemas de Gil Soeiro remiten, en la medida que son ellos mismos realizaciones palimpsésticas, a pintores, dramaturgos, cineastas, novelistas o poetas contemporáneos. Tras las referencias abrumadoras de su culturalismo se encuentra una pregunta que emerge sobre el horizonte que George Steiner ya situaba en la estela de Walter Benjamin. El «eclipse de lo mesiánico» ha cuestionado la gramática de la renovación y de la posibilidad de una futura perfección. En juego se encuentra la quiebra del binomio creación-invención. Gil Soeiro intenta repensar su relación dialéctica en sentido inverso. ¿Es posible en la combinación que da lugar a nuevas posibilidades de sentido el gesto afirmativo, casi posteológico, de la creación? Como dijo Steiner: "El sueño de Walter Benjamin de publicar un libro compuesto completamente de citas. Carezco de la originalidad necesaria. Las citas yuxtapuestas tienen un sentido nuevo y entran en mutuo debate" (Steiner 25).

Gil Soeiro deja claro desde el prólogo de Palimpsesto, bajo la significativa rúbrica de Teses sobre uma Poética Palimpséstica, que su planteamiento bebe, formal y materialmente, de la melancolía de Walter Benjamin sobre las ruinas de un origen que, en un sentido muy amplio, el pensamiento postestructuralista -más derrideano que foucaultiano en su caso- ha dejado desmantelado. Dividido en ocho breves secciones en prosa, que rehacen a su manera el estilo último benjaminiano, ahora con un alcance metacrítico desde la propia escritura poética, este prólogo comienza con una cita del segundo punto de Sobre el concepto de historia (1940) del filósofo alemán. Si Benjamín esbozaba la relación entre felicidad y redención sobre la tensión que articula el presente sobre el pasado, Gil Soeiro insiste sobre todo en el remanente mesiánico que opera en los diversos niveles con los que la tradición se sigue constituyendo textualmente. Disimula así su origen vacío sobre el horizonte del cumplimiento de sentidos siempre pospuestos. Cita Gil Soeiro a Benjamin: "¿No existe en las voces a las que ahora prestamos oído un eco de las ahora enmudecidas?" 
(Benjamin 2008: 306). Su respuesta prolonga, como una relectura, el gesto antimetafísico que Jacques Derrida tematizó en De la Gramatología. El palimpsesto de Gil Soeiro asume la escritura de la diferencia que la huella derrideana sustrae a la determinación de la significación como presencia: "la huella no es sólo la desaparición del origen; quiere decir aquí $[\ldots]$ que el origen ni siquiera ha desaparecido, que nunca fue constituido, salvo en un movimiento retroactivo, por un no-origen, la huella, que deviene así el origen del origen" (Derrida 80).

"Só podemos amar a partir de outros textos. A partir de outras mãos que assim nos iluminam a aprendizagem do desejo. E o desejo intacto será sempre recomeçar a eterna invenção do mundo, reescrevendo a latência de promessas escritas. Mas a nova caligrafia sucedânea não pretende suplantar a precedente, antes consentindo a decifração do texto rasurado" (Gil Soeiro 2016: 7).

La poética de Gil Soeiro no es exactamente escéptica ni desesperada. Más bien, ensaya bucles rítmicos y estructuras férreamente rizomáticas -como los 120 poemas del conjunto de su tetralogía, divididos en treinta por cada libro- entre los dos pronombres personales que me atrevería calificar en su caso de im-propios: yo y tú. La base de su diálogo radial es, pues, hermenéutica. En él resuenan ecos celanianos, sobre todo por este uso de los pronombres personales que le sirven, si no para continuar la senda de una poesía extremada de radicalidad del sentido que la propia poesía, como la del alemán, explora, al menos para reformular una y otra vez el propio gesto de instalar un espacio de comunicación poética mediante el poema. No se trata de que el yo pueda adscribirse a la voz del poeta y que el tú interpele al lector, ya sea en forma de los tópicos de la poesía amorosa o metapoética, ni que haya que concluir, como atribuía Gadamer a la poesía de Paul Celan, que "resulta a todas luces incierta la identidad del yo y del tú en estos poemas..." (Gadamer 12). Más bien, tras el desmantelamiento de las utopías políticas, sociales y estéticas del siglo XX, que han dejado al descubierto el vacío mesiánico que debería sostener alguna esperanza, las voces de los hablantes poéticos, incluso en su silencio, recuerdan que "la poesia no recupera el seu carácter subversiu [...] sinó quan ens mena a interrogar-nos constantment sobre la naturalesa de la poesia i de cada acte poètic" (Pons 69). Gil Soeiro se pregunta así qué resto de significación podría quedar tras la inscripción en el discurso de una voz que, al enunciar, traza su ausencia: "Toda a palavra é já um início tardío. Escrever é desmantelar a quimera da origen, desmascarar a fábula do inaugural" (Gil Soeiro 2016: 8)

Las próximas páginas no pretenden más que ofrecer una lectura a su modo palimpséstica en torno a esta singular obra que, como tetralogía, compone un retablo de preocupaciones poéticas, ensayísticas y teóricas. Abigarrados y unitarios, estos libros se despliegan en forma de cuatro paneles organizados como constelaciones de una galaxia cuyo eje depende del enfoque que sus lectores adopten ante una serie de motivos que irán reapareciendo y que podrían sintetizarse en dos, uno explícito y otro implícito: la dialéctica entre los pronombres personales "yo" y "tú", por un lado; por otra parte, el diálogo con la tradición clásica, después que la insistencia de la crítica posestructuralista en la proclama de la muerte, con Dios, del sujeto y del autor, parezca estar exigiendo una reacción, aun inquietante y exánime, para reafirmar la potencialidad creadora de la poesía aún en medio de esta ausencia. 


\section{Da vida das marionetas: Una dramaturgia del nombre inanimado}

Si para Derrida "la huella es, en efecto, el origen absoluto del sentido en general. Lo cual equivale a decir una vez más que no hay origen absoluto del sentido en general. La huella es la diferencia que abre el aparecer y la significación" (Derrida 84-85), Gil Soeiro parece invertir la perspectiva de la preocupación por el origen en un movimiento no retrospectivo sino prospectivo. La diferencia (la différance) se inscribe en el fin del origen, que no es sólo desenmascarar el origen del origen como no-origen, sino indagar los rastros que actualizan su inacabamiento como una poética del palimpsesto: el fin del sinfín interpretativo es la posibilidad más perentoria de un significado que, en la poesía, está siempre por reencontrar o por reinventar. Si se me permitiese un juego de la forma, el propio nombre de Ricardo Gil Soeiro despierta un conjunto de asociaciones onomásticas, par-onomásticas, que la lectura de $D a$ vida das marionetas puede confirmar.

Deambulando por los intersticios de las palabras como el halo de un pensamiento de un heterónimo de Bernardo Soares, Gil Soeiro ha aprendido, aunque se rebele, la lección de Álvaro de Campos: "Vivir é pertencer a outrem. Morrer é pertencer a outrem. Vivir é morrer são a mesma coisa [...] Fingir é conhecer-se" (Pessoa 1980: 263). La sintaxis de la poesía siempre condensa el lenguaje de un ultramundo, ahora ilegible. Desesperada paradoja, Gil Soeiro la afronta, como su tocayo Reis, con dignidad clásica. Allí donde la simetría y el orden se expresaban en latín, ahora recorren las múltiples lenguas de una Europa evaporada en forma de citas textuales y referencias indirectas en los títulos: una imagen fantasmal que atrapa al poeta en la tela de araña de enredados códigos culturales.

Pudiera parecer la de Soeiro una forma de ser posmoderno, y sin duda lo es, pero en ella late una resurrección -quizás, mejor, una reviviscencia- que, perdida su condición trascendente, conserva del momento estético su potencia alucinada. Su teatro de marionetas se monta entre bambalinas, donde el yo del poeta se transforma, en el movimiento inverso de Pinocho, en múltiples muñecos de madera. El protagonista poético encarna la temible pregunta que atenaza la mutilada humanidad de la marioneta, siempre al acecho en la oscuridad de la función a punto de comenzar o en el baúl cerrado tras el telón caído.

Convocados en la penumbra, comparecen en este poemario citas siniestras de Rilke, el obsesivo acorde de Stravinsky o las soledades distantes de Chirico. Los poemas giran compulsivamente en torno a los grandes temas del modernismo, a los autores de la alta cultura, tal como pueden ser leídos en este inicio del siglo XXI en el cine y el teatro de marionetas, de Takeshi Kitano a Juliette Prillard. Retomando a su modo la lección de Kierkegaard, Soeiro maneja unos hilos que se despliegan en un escenario de repeticiones, entendidas a la manera de John D. Caputo, para quien el concepto de "repetición" consistiría en "tener el coraje para el flujo" (Caputo 12). El sonido hueco de los títeres se mueve en la libertad de la muerte sin que la palabra poética apenas puede conjurarla: los poderes de Orfeo podrían seguir intactos, pero operan mudos. Las sombras siguen hechizadas el sonido del silencio.

De los maniquíes de Bruno Schulz a las piezas museísticas de los filmes de los Quay Brothers, se asiste en estos poemas a una dialéctica modernista, con la esperanza en suspenso: qué somos si las palabras sólo (se) dicen, acaso, su destino vacío. En la penumbra de lo «neutro» se lamenta una de las máscaras del poeta dentro del poema "Silogismos da amargura" en que se homenajea a E. Cioran: "De tudo me 
chamaram: / falso simulacro, criatura inverosímil; / até por mera sombra enganadora fui tomado. / Sou apenas o que sou" (Gil Soeiro 2016: 17). Utilizo el término «neutro» en un sentido blanchotiano. De hecho, entre la figura del poeta y la voz enunciadora no sólo hay un hiato, sino que se abre un espacio que la escritura del poema, en lugar de llenar, vacía, a fin de tensar las contradicciones de un habla fantasmal, hecho de ecos y de sombras. Como diría Blanchot: "«¿Qué le molesta?». -«El hecho de estar implicado en un habla que es exterior a mí»" (Blanchot 2008: XXII).

El poema explora, pues, la posibilidad de una pausa o la retracción de un decir que se desgasta y que, en su desgaste, retrasa y anticipa a la vez un sentido tanteado y desconocido:

“¿Crees verdaderamente que puedes acercarte al neutro mediante el cansancio y, mediante lo neutro del cansancio, oír mejor lo que ocurre, cuando hablar no es ver? No lo creo, en efecto; tampoco lo afirmo; estoy demasiado cansado como para eso; sólo alguien, que no conozco lo dice cerca de mí; le dejo que lo diga, es un murmullo sin importancia" (Blanchot 2008: XXIII-XXIV).

De ese murmullo incesante e in-significante, que borra sus orígenes, está hecho el diálogo desplazado de la ficción dramática que constituye el poema: "Antes ser pinóquio sonhador do que, / como tu, trovador desajeitado, / mentindo rimas imperfeitas / à boleia de astros derradeiros. / Prefiero ficar assim: / sem musa, sem amor desfeito, / sem a difícil lucidez dos infelizes" (Gil Soeiro 2016: 17)".

"Sou apenas o que sou". En la propia disposición de estos versos no encontramos sólo el eco débil, tautológico, de la manifestación divina en el Sinaí, sino también huellas de una reescritura interna a la propia obra que desdibuja sus contornos, sometiéndolos a un proceso de desmitificación que constituye la base de su propio proceso de fabulación poética, es decir, de organización de una trama que ha ido, simultáneamente, destejiendo su anécdota. La marioneta se enfrenta a su creador con una voz demediada que no es reflejo temático de un significado que el poema quisiera trasladar, sino la propia sustancia desenmascarada del fluido de sus versos: "Sou apena o que sou: / pobre alma presa por arames, / acorrentada, quem diria, / a mil e uma estrelas transparentes" (Gil Soeiro 2016: 17). Mientras que en la versión publicada en 2012 el alma estaba cogida por unos hilos finos ("finos fios") encadenados "a mil / e uma estrelas transparentes" (Gil Soeiro 2012: 13), en Palimpsesto se acentúa, irónicamente, la dimensión moral del destino de las criaturas de un mundo donde, si el espíritu ha devenido letra con la muerte de Dios, la letra ha de esforzarse por afirmar el espejismo de su espíritu. A la pregunta teológica -medieval y barroca- de si el destino humano está sometido al influjo de los astros, la marioneta de Soeiro está encadenada a una hipérbole tópica que toma, desfigurándola, de esa misma literatura.

\footnotetext{
Como enseguida se hará notar, la reescritura que el poema introduce como su tema afecta también a su propio proceder. En el caso de Da vida das marionetas y Bartlebys reunidos, publicados previamente de manera exenta, existen diferencias entre las primeras versiones de los poemas publicados y los recogidos en Palimpsesto. En el caso de "Silogismos da amargura", además de la supresión de una cita del título homónimo de E. Cioran ("Soy como una marioneta quebrada cuyos ojos hubiesen caído para dentro"), la nueva versión del poema no sólo cuenta con un verso menos, sino que, además de sustituciones de palabras, modifica el ritmo del propio poema, suprimiendo la estructura anterior de encabalgamientos abruptos que marcan una sensación de angustia desolada. Cito sólo el principio del poema en la primera versión publicada: "De tudo me chamaram: / falso simulacro, criatura / inverosímil; e até por mera / sombra enganadora me tomaram” (Gil Soeiro 2012: 13).
} 
Como puede deducirse, una lectura comparada de la primera edición de Da vida das marionetas (Gil Soeiro 2012) con la que se recoge de Palimpsesto (Gil Soeiro 2016) ofrece cambios no sólo de palabras sino también de ritmos, a través de diferencias en la escansión de los versos, así como de modificaciones paratextuales en los títulos de los poemas, en la supresión de citas y hasta en la sustitución muy significativa de un poema por otro en un lugar muy sensible de la arquitectura de todo el poemario ${ }^{5}$.

Me gustaría detenerme brevemente en tres poemas donde estos cambios son más remarcables, tanto porque tienen lugar en puntos cruciales como porque afectan a una reorientación de la finalidad del propio libro. Me refiero a los dos últimos poemas del libro. En la edición de 2012 cerraban el volumen los titulados "O sonho de Pigmaleão" y "Coda: Breve nota sobre a melodía das coisas" (Gil Soeiro 2012: 46-48). En la edición de 2016, este último, que pierde la cita de Rainer Maria Rilke tomada de Noticias sobre la melodía de las cosas (1898), pasa a ocupar el lugar del poema que, situado a la mitad del libro aproximadamente (número 17) con el título de "L'Odyssée rêvée ou Ulysse en personne: Juliette Prillard, 2012", desaparece ahora del conjunto. Como cierre del libro se añade un poema titulado "Desenlace" (Gil Soeiro 2016: 48).

Estas variaciones no son menores en la medida que ponen en juego la arqueología mitológica que sustenta la lucha entre los dioses y los hombres que, en la época del eclipse del logos, se invierte entre las marionetas y quienes sean que muevan sus hilos. En cierto modo unamuniana, por la ficción que sostiene la agonía creativa entre el creador y sus criaturas, esta tensión acentúa sus rasgos autorreferenciales que experimentan la belleza no en el deseo del conocimiento que había anidado en el eros platónico, sino la posibilidad extrema y rota de un amor que se caracteriza por la fragilidad de llegar siempre a destiempo. El amor, como la belleza, sería el reino de la carencia.

Con una cita de El señor de Pigmalión (1921) del autor español Jacinto Grau, el poema "O sonho de Pigmaleão" reescribe el mito invirtiendo, como digo, la situación. Son las criaturas quienes "por fim, gritando pelo direito à existência, / transformam-se, afinal, en seres de carne e osso, / graças ao meu ardor de escultor apaixonado" (Gil Soeiro 2016: 47). La búsqueda de la autodivinización en su creación aboca al poeta a querer ser refigurado en un canto del que, definitivamente, está exiliado: "[...] como eles, quereria desnudar-me / em pleno canto aberto, modo singular / de me resolver em imortal metamorfose" (ibíd.) ${ }^{6}$.

No es por ello casual que la contrafigura del poeta que es Ulises desaparezca en la edición de 2016, al preferir ésta una mayor precisión teórica en los cambios que in-

Los cambios de títulos afectan a ocho de los treintas poemas, mientras que la supresión de citas afecta a nueve poemas. Es decir, más de una cuarta parte del poemario inicial se ve transformado en sus paratextos. En más de la mitad de los casos las variaciones optan por reducir uno de los rasgos que caracterizaba el libro primeramente publicado: las referencias culturales a literatura, cine, pintura o filosofía, en beneficio de un planteamiento más teórico en línea con el conjunto de la tetralogía y menos sujeta, así, al diseño primitivo basado en una referencialidad hipertextual. Así "La moglie diGogol: Tommaso Landolfi, 1954" pasa a llamarse "A desaparição do rosto"; o "Strings: Anders Klarlund, 2004" simplemente "Fios"; "Shadow Gathering: Blane de St. Croix, 2003" es ahora "Primeira fila", "Schoolboy Play: Roman Paska, 2010" se retitula "Coreografias do incerto"; y "Marche funèbre d'une marionnette: Charles Gounod, 1882" queda reducida a "Último acto".

6 A diferencia de la versión de 2016, en 2012 la tendencia es menos abstracta y teórica, más inclinada a una pulsión de luminosidad física que contrasta con la oscura densidad de lo inanimado. Nótense los cambios adjetivos, nominales y verbales, además del cambio métrico: "[...] como eles, quereria / desnudar-me em canto incandescente maneiras / de me tornar em imortal metamorfose" (Gil Soeiro 2012: 46). 
troduce, a cuenta de las referencias artísticas paratextuales de las versiones de 2012. Como se volverá a comentar a propósito de Comércio com Fantasmas, parece como si el poeta en la revisión de su obra, más que borrar las huellas del mito o reorientar su significación, hiciese del palimpsesto la dinámica misma de su escritura. En la tarea de borrado experimentaría de una manera más penetrante el movimiento de significación que, desplazando sus signos, organiza su propia tradición.

Inscrita en la lección de las vanguardias, la poesía de Gil Soeiro retiene, sin embargo, el gesto destructor de aquellas mediante un diálogo inacabado que es tanto una búsqueda como una declaración de amor conscientes de su ilimitada finitud. En la primera edición de Da vida das marionetas Ulises es un "apócrifo trovador", "poeta o herói dos mils ardis" para quien es duro estar exiliado. El poema, y por extensión la obra, significa y se convierte en el palimpsesto que marca la ausencia de su nombre y de sus palabras: nadie, nada. Él "vira do avesso páginas / rasgadas onde esboça poemas como este- / apenas um punhado de nódoas esquecidas, / miragens que o amor decidirá consentir" cuando la consolación de la palabra se manifieste sólo como un artificio "de astuta circe feiticeira". No por ello el Ulises de Gil Soeiro se entrega a un silencio nihilista, sino que descubre que en el laberinto por donde naufraga "outras histórias esperarão / a sua naufragante eternidade" (Gil Soeiro 2012: 30-31). El poema, pues, como el palimpsesto que define el DRAE, es siempre, por el retraso que desenmascara la fábula de cualquier origen, una actualización del "manuscrito antiguo que conserva huellas de una escritura anterior borrada artificialmente".

No es casual que en el juego de espejos y de espejismos cuyos significados se exploran alrededor de sus puntos ciegos, el lugar que ocupaba el poema sobre Ulises sea reemplazado en Palimpsesto por aquel que cerraba el libro en su primera edición. Los significantes olvidados son manchas verbales que ponen en juego el movimiento de aquella huella que Derrida consideraba que "está necesariamente ocultada, se produce como ocultación de sí. Cuando lo otro se anuncia como tal, se presenta en la disimulación de ś́" (Derrida 61). Operan una des-motivación que en la forma del poema sólo el amor, como su vínculo creador, es capaz de consentir o de acordar, en su doble y ambiguo sema de acuerdo y de acorde, pragmático y rítmico.

De hecho, el amor de no ser queridas mueve los juegos pronominales (yo y tú) de las marionetas de Soeiro. La obsesiva insistencia en el "eu" de los primeros quince poemas prepara, en los otros quince, una reflexión metapoética en torno a la existencia incierta que teje el diálogo con el tú del lector, figuración soñada entre los saltos de los versos. Siempre amenazado por una muerte presentida, el poema, de entre los signos, engendra un espacio de fulguraciones que el ritmo perpetúa: "Quando, esquecido, regressares das estrelas / mais tardías, reconhecerás, afinal que terei / sido sempre eu a fiel morada que buscavas. / Então, e só então, / perdurarei eu, mortal e imperfeito, / no rasto de cinza que deixares" (Gil Soeiro 2016: 43).

Por ello, en el poema "Matéria em movimento", en una discusión casi (anti)platónica, se considera que morir es absurdo, una belleza despilfarrada. Si en el Fedón Sócrates sostenía que la filosofía es una preparación para bien morir, la búsqueda del método requiere de él un deseo de purificación que le empuja a una segunda navegación: "Opiné, pues, que era preciso refugiarme en los conceptos [lógoi] para examinar en ellos la verdad real" (Platón 109). A esta verdad por participación que proporciona un nuevo conocimiento se llega movido por una erótica de la reminiscencia. En los conceptos están inscrita el ansia de lo que nos falta. Sin negar el vínculo, el palimpsesto de Soeiro pone a prueba, en cambio, la naturalidad del mismo. 
En la huella no hay remisión a un origen, sino una fulguración pospuesta, reconocida cuando ya es demasiado tarde. El amor de la belleza culmina en el acto de su desposesión. La voz en forma de poema, que acoge, impotente, el rumor de los naufragios lectores, intenta salvar las dovelas dispersas del sentido. Es absurdo morir, porque, con intensa melancolía, nos resistimos al olvido para que la herida de ser no deje nunca de cicatrizar.

“As coisas não se mexem:
só o mar é sem repouso,
quase sublime
no desamparo que nos traz.
Estão incompletas:
é proprio das coisas
serem estrelas imperfeitas.

Buscam a palavra que lhes falta, carecem de um fulgor exacto.

É por isso que se escreve sempre em atraso.

Nas palavras é sempre un pouco tarde de mais.

Escreve-se apenas o que o tempo consente.

Amase a amargura de jamais se encontrar paz" (Gil Soeiro 2016: 32).

\section{Bartlebys reunidos: La abstención creadora como una ética de la impotencia.}

En una teoría palimpséstica como la que propone Ricardo Gil Soeiro a lo largo de su tetralogía, podría decirse que cada libro avanza arrancando capas a las intuiciones centrales que articulan el conjunto. Entre ellas, como ya se ha mencionado, destaca el hecho de que la escritura -y la escritura poética como su decantación radicalacontece siempre después. Más que de una caída o de una herida original, que permanece como la fábula que permite a la voz poética en primera persona constituirse como tal, el lugar de la poesía es un exilio. Fuera de su suelo (ex-solum), arrancado de él, desolado, el palimpsesto de Gil Soeiro no se limita a grabar las palabras encima de un texto cuyo sentido testimonia el movimiento en fuga de toda tradición. Palabras clave como silencio o vacío, en medio de un firmamento lleno de estrellas que se definen como incompletas o imperfectas, remiten a la sustracción que opera el mismo palimpsesto. Cada poema explora, a su manera cansada y reactiva, los intersticios que fecunda el gesto creador, el cual, al inscribir la diferencia en aquel texto siempre en cambio, mediante una enunciación que desvía los significados que la situación comunicativa procura, siempre en tensión entre el yo y el tú, llega, por eso, diferido, en retraso, al lector, no como elemento de cierra del proceso comunicativo, sino como la posibilidad de desplegar los efectos de sentido que los poemas han explorado impotentes.

Podría decirse que en lo dicho se sustrae lo que queda por decir. Lo por decir no puede completarse en algo dicho de una manera más plena. Lo por decir es lo que no se puede decir en absoluto en y de lo dicho, aunque sea la promesa de una inteligibilidad que lo excede. Tal afirmación debe ser entendida, bajo unos términos derrideanos, como un subtexto de resonancias blanchotianas en la obra de Gil Soeiro. La 
tarea del crítico es quedar a la escucha, incierta, de lo que pudiera no llegar. Así, a $D a$ vida das marionetas Ricardo Gil Soeiro ofrece el contrapunto de Bartlebys reunidos, libro con el que pretende explorar una "ética de la impotencia".

Si en el primer libro refulgían imágenes teatrales, cinematográficas o plásticas de esa inquietante figura, semihumana y semidivina, casi inerte, que es la marioneta, en este segundo se perfila, sobre todo a través de escritores y filósofos, un retrato de Bartleby (1856), el protagonista del relato homónimo de Herman Melville, construido casi de una manera cubista que incluye diversas perspectivas y dimensiones.

Si la modernidad había asistido fascinada al nacimiento de Don Juan -el de Tirso de Molina y el de W. Mozart \& Lorenzo da Ponte--, que, abrasado, se disemina entre tantas conquistas, Gil Soeiro propone como modelo mítico de nuestro mundo crepuscular la abstención de los Bartlebys $-I$ would prefer not to- que pueblan y que atormentan, explícitamente o no, los escritorios revisitados de Kafka y Blanchot, de Walser y Deleuze o de Hofmannsthal y Rimbaud. El crepúsculo del ser proyecta un teatro de sombras que la voz poética persigue ante el silencio de sus interlocutores.

Como ocurría en Da vida das marionetas, entre la edición de 2013 y la de 2016 se produce el mismo fenómeno que se ha calificado anteriormente de palimpséstico estructuralmente. En un porcentaje similar, Gil Soeiro cambia los títulos de poemas, sustituyendo aquellos que incluían la obra y el nombre de un autor por otros cuya función genérica responde mejor al diseño global de toda la tetralogía que a los efectos culturalistas del libro publicado de manera exenta ${ }^{7}$.

Si alguna figura literaria encarna los rasgos de Bartleby a lo largo de los intrigantes e intensos poemas de Gil Soeiro, es Fernando Pessoa. Presencia fantasmal, acechante, como la del padre de Hamlet, el poeta se enfrenta a ella con una serie de inteligentes dispositivos que, al tiempo que bucean en las posibilidades de sus magmáticas personalidades poéticas, intentan disiparlas mediante encabalgamientos y versos «erróneamente» escandidos en la edición de $2013^{8}$.

Según Jacques Lacan, el padre no muere nunca, aunque el deseo sólo pueda operar sobre su ausencia: "la aparición de la palabra representa antes que nada un corte simbólico que inscribe en la condición humana la dimensión de lo imposible" (Recalcati 33). El poeta sabe que, tras cada Bartleby, asoman desvanecidos la sombra de los heterónimos pessoanos. Como uno más de ellos, reconoce en el espejo de la

Así, por ejemplo, los poemas 3 al 6 cambian sus títulos: "Bartleby o que foi poeta, 2011: Luis Filipe Castro Mendes" por "Impotência creadora"; "Tractatus Logico-Philosophicus, 1921, §7: Ludwig Wittgenstein" por "Erro de cálculo"; "Un homme qui dort, 1967: George Perec" por "Recaída"; "História do Escrivão Bartleby, 2003: Francisco Luis Parreira” por “Ainda que a faca não corte o fogo”. Es llamativo también que el título del poema epitafial "Paul Celan (1920-1970)", a diferencia de lo que ocurre con Robert Walser y Franz Kafka, sea cambiado por "Biografia dos tumultos" y que del título del poema "A escrita dos desastres, 1980: Maurice Blanchot" se suprima sólo la fecha y el nombre. Los poemas dedicados a Herman Broch, Hugo von Hoffmanstal, Gilles Deleuze, Jorge Luis Borges, Giorgio Agamben, Javier Zabala o Hermann Melville permanecen en ambas ediciones con idéntico título. En contraposición con Da vida das marionetas, todas las citas se mantienen (M. Blanchot, G. Deleuze/F. Guattari, C. Lispector...).

8 En Palimpsestos (2016) hay una tendencia general a resolver la violencia de los encabalgamientos de los dos libros publicados exentos en que un pronombre átono o un pronombre relativo o una preposición o una conjunción quedaba separados versalmente del resto de la oración que introducían. Entre las operaciones practicadas destacan la reducción métrica del verso y el consiguiente, aunque no necesaria, aumento del número de versos. Sin embargo, en Bartlebys reunidos permanecen no pocos de estos. Al azar, por ejemplo: "E eu, que me reconheço mero / intruso indeséjavel, insisto em / espiar-lhes remorsos impossíveis" (Gil Soeiro 2016: 75). 
escritura su imagen de Telémaco, funámbulo sobre el vacío que ha dejado una autoridad que parece hacer de su regreso una negación pospuesta. Viaja, por ello, sin desmayo entre los márgenes de la cultura europea en busca de las preguntas más tersas, a fin de conjurar el peso latente de una paternidad imposible. Angustia y cansancio apenas velan la vigilia alucinada, que no desiste de reconocer en la letra impotente el espíritu eclipsado de cada acto de lectura.

Para Pessoa "vivir la vida en Extremo significa vivirla hasta el límite" y de entre sus maneras él prefería "sustituir por la Inteligencia la energía, romper el lazo entre la voluntad y la emoción, despojando de interés todos los gestos de la vida material": "Decían los argonautas que navegar es preciso, mas vivir no es preciso. Argonautas nosotros de la sensibilidad enfermiza, digamos que sentir es preciso, mas que no es preciso vivir" (Pessoa 2003: 140-142). A Jasón Gil Soeiro opondrá las rutas laberínticas de Ulises, pues es consciente de que el nihilismo posmoderno, si quiere evitar la impostura y la banalidad del chisporroteo elegante, no tiene otra salida que tantear los oscuros pasadizos subterráneos que lo unen con el modernismo centroeuropeo. Bajo la advocación anglosajona de Melville, visita los pasajes de un lenguaje que remiten a la explosiva iluminación de lo que desaparece en él. Los ejemplos de la literatura alemana y de la filosofía francesa dejan sus rastros en los silencios dialogados de estos poemas, sin que extrañe que, entre los escritores en lengua española, el homenaje a Vila-Matas, con una cita inicial de su Bartleby y compañía (Gil Soeiro 2016: 51), se recueste sobre el recuerdo de Borges en "Prólogo a Bartleby, 1943: Jorge Luis Borges" mediante los motivos del laberinto, el naufragio, los libros: "Sem mares revoltos, desconhece o seu destino, / pronunciando apenas contundentes subtilezas" (Gil Soeiro 2016: 87).

Si los clásicos acogían la palabra como el don que creaba el espacio compartido de la memoria, a los posmodernos les sorprende y les deslumbra el olvido que adivinan tras sus ecos. En Ovidio, Leandro puede arrojarse al mar de las palabras como gesto supremo de desesperación amorosa: "De que para mí no hubiese sino un camino así me quejaba antes; / pero ahora de que también éste me falta por el viento me quejo" (Ovidio 1986: 155). Para Hermann Broch en La muerte de Virgilio (1945), el éxtasis de la muerte salvará del fuego los versos de Virgilio, pero para Soeiro esta afirmación impone la condición del cansancio: "aceita este poema inútil: / é o que tenho, o que sou // ouves os meus passos?". En el bucle metapoético que refleja su propio libro ("Uma noite com Bartleby, 2010" retitulado en 2016 "Antologia panorâmica das despedidas"), constata desesperado esta ausencia constitutiva de sus versos a la vez bíblica y helénica, bajo la figura otra vez de Ulises-: "Naufrágios são tudo o que tenho: / indicios rumo ao desconhecido. / Naufrágios -o que são? /As palavras são palabras, / eu sou quase eu" (Gil Soeiro 2016: 91).

De hecho, todo el libro de Bartlebys reunidos, subtitulado "30 poemas em forma de nota de rodapé a um texto invisível", relata un viaje circular cuyas jornadas se evaporan bajo los signos trazados en cada una de sus páginas. El poeta interroga su identidad a través de la angustia perpleja por la realidad de lo otro. Cada poema es un descenso a la noche o un naufragio órfico en la que la tarea de levantar los versos desea y se proyecta a un abismo lingüístico que le permita entrar en contacto con una realidad otra del sentido que se siente próximo pero que parece infranqueable: "aquello con lo que uno se une, la repetición que no termina, la saciedad desprovista de todo, el centelleo de lo que es sin fundamento y sin profundidad" (Blanchot 1992: 158). 
Los pronombres "yo" y "tú" se entrelazan a la búsqueda de un reflejo que, de un modo inquietante, va emergiendo en los blancos -en las cursivas que Gil Soeiro va grabando dispersas entre sus versos- que el poema intenta condensar. Trazando las huellas de lo invisible, las formas se desdoblan recortándose en esquirlas de un posible sentido. El poema se convierte así en un espacio impotente donde se indaga el residuo creador de una negatividad que late en las sílabas que organizan constelaciones, apenas entrevistas, de sombras significativas, como en el caso de "O jogo de fazer versos":

"Todavia, não me rendo: sei bem de quem é a culpa e, assim, apunto o dedo acusador. Às minhas prezes fez ouvidos mocos a triste arte das palavras e injustose me afigura este castigo.

$\mathrm{O}$ que eu queria era mares de veludo, susurrando desamores perfeitos; não estas sobras desmedidas, incessantemente repetindo acordes desiguais -alçapão de rima pobre. Mas não há maneira de mitigar este mal de que padeço.

¿Sofrer?

Sofra quem lê" (Gil Soeiro 2016: 79).

Escribiendo tras los versos silencios susurrados, Soeiro testimonia, sin esperanza, la certeza de unas palabras oscurecidas. Quien sepa leerlas, permanecerá a la escucha de lo que no puede llegar. Tal vez la lectura aquí propuesta sea demasiado nietzscheana, destacando sobre todo el momento reactivo de la creación en lugar de la plenitud creativa que la palabra guarda incluso en la negación, tal como el propio Gil Soeiro ha hecho notar: "trata-se, creio, de uma negatividade de que, paradoxalmente, pode ser terreno fértil para a afirmação da criação, para o triunfo do gesto; enfim, para a plenitude da palavra" (Pego Puigbó 2013b). Matizaría, así, este argumento, diciendo que es posible descubrir en los poemas individuales de estos Bartlebys tanto heterónimos "del" poeta como la conciencia de que éste se "heteronomiza" al tomar la palabra poética.

\section{Comércio com Fantasmas y Anjos necessários: los espectros de Ovidio y Sócrates}

Si se permitiese dar una vuelta de tuerca más, cabría insistir en que esta dialéctica remite paradójicamente a otro origen que no es el de la (post)modernidad con el que continuamente los poemas de Ricardo Gil Soeiro dialogan en un tenso contrapunto, como ocurre en sus revisiones de F. Pessoa e incluso de T. S. Eliot ${ }^{9}$. Se trata del

$9 \quad$ El ejemplo más claro de una lectura pessoana de T. S. Eliot se encuentra en el poema en tres partes de Comércio 
mundo clásico que, expropiado, regresa fantasmal para exigir el rescate -la venganza desposeída- de su olvido, como ocurre de modo destacado tanto en Comércio com fantasmas como en Anjos necessários, los dos volúmenes hasta ahora inéditos de la tetralogía.

El poeta, como un Ulises órfico, se aventura tras la máscara del decir donde a la fábula de un deseo ausente se opone una resistencia que abre una reescritura que, en ruinas, aunque no inacabada, no se da por vencida. Gil Soeiro define con exactitud este movimiento en las Tesis sobre uma poética palimpséstica con que se abría Palimpsesto bajo la tutela de Walter Benjamín: "O sentido não tem fin. Porque no começo está a ruína, o sentido está sempre por vir" (Gil Soeiro 2016: 9). Tras estas palabras se puede escuchar, además de Benjamin, también el eco antimetafísico con que Blanchot define el desplazamiento constitutivo del acto poético: "La esencia de la literatura es escapar a toda determinación esencial, a toda afirmación que la estabilice o incluso la realice: la literatura nunca está ahí ya, siempre está encontrar o por reinventar" (Blanchot 2005: 237). ¿Es posible reencontrarla o reinventarla en la determinación que desfigura su tradición?

Una lectura atenta de Comércio com Fantasmas deja un sabor a palimpsesto de literatura latina. La lección de Ovidio, que se ha mencionado a propósito de Bartlebys reunidos, se hace más perentoria en estos poemas que intentan tejer, como indica el subtítulo, "uma epistolografia espectral". No remite ahora tanto a las Heroidas como a Tristia, que es un epistolario de destinatario incierto, en domicilio fugaz. En él el amor y el exilio conjugan una cópula que se consuma interrumpida: "Además, si llevaras contigo, libro mío, todos mis pensamientos, serías un fardo demasiado pesado para el que te va a transportar. Largo es el camino, ¡date prisa! Por mi parte, voy a habitar en el último confín del mundo, en un país apartado de mi patria" (Ovidio 1992: 83). Culminado en la figura de Ulises, el libro de Tristia aúna la elegía y la epístola en torno al mito que "se vuelve urgencia íntima y fuerza modeladora del propio destino" (Guillén 40) ${ }^{10}$.

El género de la carta abre un espacio, que más allá de su temática sobre el amor y la amistad, ensaya la capacidad de la palabra poética por saltar sobre el discurso de la identidad del emisor y su destinatario. Radicalizada, cada carta es el esbozo de unos rostros que se disuelven en la gramática de las caricias evaporadas por la mano que tinta - que mancha- el mapa de sus sentidos por venir, como plantea el poema "Incipit" que abre esta sección.

"De fantasma para fantasma, escrevo para te dizer que há palavras mudas que nos despem.

Segredos que permanecerão entre nós.

Entretanto, talvez a vaga certeza de

com fantasmas que se titula "Correlato Subjectivo: os direitos do leitor" y que comienza así, poniendo de nuevo en práctica la hermenéutica de los deícticos: "Talvez nunca venhas a saber / se a minha angustia é real ou / mera ilusão de aprendiz de fingidor" (Gil Soeiro 2016: 129).

10 Comércio com Fantasmas introduce una variante ausente en los otros tres libros. Tres "poemas" están escritos en una prosa ensayística, literaria, pero no se les puede calificar ni de "poema en prosa" ni tan siquiera de "prosa poética". "Em caso de extravio" (Gil Soeiro 2016. 131-133) retiene cierta narratividad siempre pospuesta. "Aviso de recepção" acentúa el tono de reflexión metapoética, mientras que el final "Post-scriptum" actúa a modo de clave de lectura crítica del conjunto de este libro. 
não existirmos chegue para compensar o medo de trocarmos desertos de luz.

Ficaremos a espera um do outro:

murmurando confidências e mentindo

absolvições com quem ofrece ao vento

a eternidade de incontáveis cartas vazias.

Cartas como beijos escritos que jamais

chegarão llegarán ao seu porto do abrigo.

Ficarei aqui, neste pedaço de papel,

aguardando, com se fosses caminho" (Gil Soeiro 2016: 104)

Desde este punto de partida, el lector, amante espectral, acaba sobrescribiendo su nombre sobre la interrogación que el poema cierra a tientas, entre los paréntesis que se desbordan incluso en una escritura poemática. A diferencia de Pessoa, no es sólo el poeta sino el lector quien finge en su silencio el silencio que, dolorido, no guarda aquel ("O leitor é um fingidor, a voz que só a ti te devo") (Gil Soeiro 2016: 140), como describe para cerrar su libro el texto prosístico "Post-scriptum: a geometría da carta": "Bem vistas as coisas, é muito parecida com a poesía a arte epistolar: a sua paixão pelo vazio, a propensão para palavras que acendem solidões, a encenão de uma sempre inacabada conversa entre fantasmas" (Gil Soeiro 2016: 144).

La naturaleza de estos fantasmas es, en último término, angélica. El ángel de Gil Soeiro tutela el comercio espectral de unas marionetas que se abstienen de ser y que, por ello mismo, inscriben de nuevo las letras de posibles sentidos sobre aquello -el poema- que, inanimado, queda como huella de una epístola errante. Su ángel no es rilkeano, sino aquel que conjura, melancólico, el apocalipsis inmanente de Benjamin.

Se indicó al principio que es constante, en su imaginería y hasta en el moldeado de sus reflexiones en prosa, la remisión a las Tesis sobre la historia, entre las que sobresale, además del famoso comentario dedicado al ángelus novus de Klee, su comienzo con la figura de un autómata movido escondidamente por un enano jorobado que era maestro en ajedrez: "Puede imaginarse un equivalente de este aparato en filosofía. Siempre debe ganar el muñeco llamado «materialismo histórico», pudiendo enfrentarse sin más con cualquiera si toma a la teología a su servicio, la cual, hoy día, es pequeña y fea, y no debe dejarse ver en absoluto" (Benjamin 2008: 305). Si el mesianismo de Benjamin alegorizaba la teología proscrita del materialismo histórico, Gil Soeiro interroga entre los restos del siglo XX las posibilidades apenas afloradas, estéticamente, del "tiempo del ahora":

"La verdadera imagen del pasado pasa súbitamente. El pasado sólo cabe retenerlo como imagen que relampaguea de una vez para siempre en el instante de su cognoscibilidad. [...] Por cuanto es una imagen ya irrevocable del pasado que amenaza disiparse con todo presente que no se reconozca aludido en ella" (Benjamin 2008: 307).

En la figura del ángel, como el eclipse de la imaginación solar de Occidente, puede acaso, finalmente, explicarse la ausencia de las trazas daimónicas de Grecia que va pavimentando, como "uma escrita do desejo", el transcurso de Anjos necessários: "Simplesmente amo tudo o que / jamais me poderá pertencer. / Digo amor porque 
não conheço / outra palavra para beleza" (Gil Soeiro 2016: 150). A la belleza terrible que intuyen estos poemas, que bucean en E. A. Poe y Wallace Steven o en Heiner Müller o Wim Wenders, de alguna manera podrían aplicarse, como un epitafio, las palabras con que Allan Bloom define la vida filosófica de Sócrates: "puede contener todas las formas de vida, pero en un sentido que es totalmente ajeno a quienes la llevan. Es justicia sin la ciudad, piedad sin dioses, Eros sin cópula ni reciprocidad" (Bloom 569).

En efecto, el poeta, que cabe repetir que en Gil Soeiro es un Orfeo que naufraga por los laberintos de la memoria y del deseo, tiene, como Sócrates, un dáimon, algo intermedio entre mortal e inmortal, que "interpreta y comunica a los dioses las cosas humanas y a los hombres las de los dioses" (Platón 247). Es este intermedio erótico donde resplandece momentáneamente la belleza que, tanteada por la palabra, llega siempre después, con retraso, como la historia de Ulises, in medias res, conservando la melancolía irrecuperable de un futuro en ruinas como el que cierra la tetralogía con el poema "Falsa partida": "No fim de contas, somos apenas deuses / menores do instante, intercedendo por / um fio de sangue ou nota derradeira que / não chega para salvar os restos do silêncio: / sim, a mesma falsa partida de sempre" (Gil Soeiro 2016: 183).

\section{Conclusiones palimpsésticas}

A lo largo de estas páginas se ha intentado resaltar la personalidad de la voz poética de Ricardo Gil Soeiro en su tetralogía Palimpsesto, cuya escritura no se limita a una mera reflexión y práctica de juegos de intertextualidad, actualizados según los procedimientos de una jerga posmoderna. La obra de Gil Soeiro incluye una poética que toma como referencia a Walter Benjamin, aunque, de acuerdo con el planteamiento que se ha defendido aquí, debe ser leída sobre el fondo deconstructivo de una relectura hermenéutica de Maurice Blanchot, Es la obra y no sólo su temática la que se constituye como un movimiento dialéctico -y recíproco- de escritura y borrado, que encuentra su concreción alegórica en las figuras «daimónicas» de Orfeo y de Ulises, a través de las tensiones entre los deícticos personales, entre las figuras enmascaradas del poeta y del lector o entre los ideologemas de la belleza y la palabra poética. En el fondo, lo que el autor plantea es cómo en la época del eclipse de la palabra -o, si se quiere, del logos clásico- es posible todavía explicarse, una vez desfundamentada, el concepto de tradición que ha estado asociada a la cultura occidental.

Por ello, quizás sea apropiado cerrar este itinerario con un poema de Anjos necessários titulado "La Chute de l'Ange, 1941: Marc Chagall”. En él puede observarse una serie de motivos característicamente antimodernos, por usar el rótulo acuñado por Antoine Compagnon, que son tratados desde una ambivalencia crítica: la caída, la nostalgia del paraíso y el pesimismo "que no conduce a la apatía [...] sino al activismo: da la energía de la desesperación" (Compagnon 98). Operando una tarea de desgaste "palimpséstico" sobre ellos, el propio poema se convierte en su palimpsesto. Aunque la referencia sea el cuadro La Chute de l'Ange el poema incluye otra referencia que sobrepone en los versos otro cuadro tardío del mismo Chagall, La Chute d'Icare (1974-1977). La tradición bíblica y la mitológica, sobre el fondo del sufrimiento inhumano del siglo XX, se con-funden en una revisión de la cultura 
europea que contiene, con los gérmenes de la barbarie, la posibilidad inexplicable de una esperanza ausente. Sin orígenes, la conjetura de esta caída sería si no abismal.

"Caímos uma e outra vez.

Somos a própria queda em estado puro.

E, se acaso chegamos a voar bem alto, logo regressamos ao chão do mundo, onde encenamos, sem engenho, o infeliz destino de um Ícaro demasiado sonhador. Guardamos dentro das veias a vaga recordação de um paraíso perdido. Persegue-nos a nudez da nostalgia, a escuridão de uma insuportável saudade. Caímos siempre.

Uma e outra vez" (Gil Soeiro 2016: 168).

\section{Referencias bibliográficas}

Bajtin, Mijail (1989): Teoría y estética de la novela. Trad. H. S. Kriúkova y V. Cazcarra. Madrid: Taurus.

Baudelaire, Charles (1861): Les fleurs du mal. París: Poulet-Malassis et de Broise (http:// gallica.bnf.fr/ark:/12148/bpt6k6151252j/f21.image).

Benjamin, Walter (2008): Obras. Libro I / vol. 2. Trad. A. Brotons Muñoz. Madrid: Abada Editores.

Blanchot, Maurice (1992): El espacio literario. Trad. V. Palant y J. Jinkins. Barcelona: Paidós Ibérica.

Blanchot, Maurice (2005): El libro por venir. Trad. C. Peretti y E. Velasco. Madrid: Trotta.

Blanchot, Maurice (2008): La conversación infinita. Trad. I. Herrera. Madrid: Arena Libros. Bloom, Allan (1996). Amor y amistad. Trad. C. Gardini. Santiago de Chile: Andrés Bello.

Caputo, John D. (1987): Radical Hermeneutics. Indianapolis: Indianapolis University Press. Compagnon, Antoine (2007). Los antimodernos. Trad. M. Arranz. Barcelona: Acantilado.

Derrida, Jacques (1971): De la Gramatología. Trad. O. del Barco y C. Ceretti. Buenos Aires: Siglo XXI.

Gadamer, Hans G. (1999): ¿Quién soy yo y quién eres tú? Comentario a Cristal de aliento de Paul Celan. Trad. A. Kovacsics. Barcelona: Herder.

Genette, Gerard (1989): Palimpsestos. La literatura de segundo grado. Trad. C. Fernández Prieto. Madrid: Taurus.

Gil Soeiro, Ricardo (2009): Iminência do Encontro: George Steiner e a leitura responsável. Lisboa: Roma Editora.

Gil Soeiro, Ricardo (2012): Da vida das marionetas. Ribeirão-V. N. de Famalicão: Ediçỡes Humus, 2012.

Gil Soeiro, Ricardo (2013): Bartlebys reunidos. Porto: Deriva Editores.

Gil Soeiro, Ricardo (2016): Palimpsesto. Porto: Deriva Editores.

Guillén, Claudio (1998): Múltiples moradas. Ensayos de Literatura Comparada. Barcelona: Tusquets.

Kristeva, Julia (1997): “Bajtín, la palabra, el diálogo y la novela". En Desiderio NAVARRO 
(selecc. y trad.), Intertextualité. Francia en el origen de un término y el desarrollo de un concepto. La Habana: UNEAC-Casa de las Américas-Embajada de Francia, pp. 1-24.

Luján Atienza, Ángel (2005): Pragmática del discurso lírico. Madrid: Arco/Libros.

Ovidio, Publio (1986): Heroidas. Trad. Fca. Moya del Baño. Madrid: CSIC.

Ovidio, Publio (1992). Tristes. Pónticas. Trad. J. González Vázquez. Madrid: Gredos.

Pego Puignó, Armando (2013a): "Las marionetas de Soeiro". En https://guidocavalcanti. blogspot.com.es/2013/02/las-marionetas-de-soeiro.html.

Pego Puigbó, Armando (2013b): “Soeiro y Bartleby escriben sus silencios”. En https://guidocavalcanti.blogspot.com.es/2013/05/soeiro-y-bartleby-escriben-sus-silencios.htm.

Pego Puigbó, Armando (2016): “Los dáimones tatuados de Ricardo Gil Soeiro”. En https:// guidocavalcanti.blogspot.com.es/2016/08/los-daimones-tatuados-de-ricardo-gil.html.

Pessoa, Fernando (1980): Textos de Crítica e de Intervenção. Lisboa: Ática.

Pessoa, Fernando (2003): Libro del desasosiego. Trad. P. E. Cuadrado. Barcelona, Acantilado.

Pons, Arnau (2014): "Poesia i veritat". En Paul CELAN, Cristall d'alè = Atemkristall Trad. A. Pons. Barcelona: LaBreu, pp. 51-81.

Platón (1992): Fedón. Banquete. Fedro. Trad. C. García Gual, M. Martínez Hernández y E. Lledó. Madrid: Gredos.

Recalcati, Massimo (2014): El complejo de Telémaco. Trad. C. Gumpert. Barcelona: Anagrama.

Steiner, George (2011): Gramáticas de la creación. Trad. A. Alonso y C. Galán Rodríguez. Madrid: Ediciones Siruela. 